\title{
A Science Show Debate: How the Stasi Staged Revisionism - CORRIGENDUM
}

Till Düppe

doi:10.1017/S0960777320000168, published by Cambridge University Press, 21 April 2020

The above article was published with an error in the first paragraph of the third page. The sentence 'This would result in Benary being stripped of his higher functions and the end of Benary's academic career.' should read:

'This would result in Behrens being stripped of his higher functions and the end of Benary's academic career.'

The author apologises for this error.

\section{Reference}

Düppe, T. (2020). A Science Show Debate: How the Stasi Staged Revisionism. Contemporary European History, 1-19. doi:10.1017/S0960777320000168

Cite this article: Düppe T (2020). A Science Show Debate: How the Stasi Staged Revisionism - CORRIGENDUM. Contemporary European History 29, 372-372. https://doi.org/10.1017/S0960777320000193

(c) The Author(s) 2020. Published by Cambridge University Press 